https://doi.org/10.5817/OS2021-1-11

\title{
О костюмной поэтике в прозе А. П. Чехова
}

АБИЕВА, Н. М.: Поэтика костюма в прозе А. П. Чехова: монография. Барнаул: АлтГПУ, 2018. 230 с. ISBN 978-5-88-210-920-1.

Рецензируемая монография посвящена системному анализу поэтики костюма (костюмной детали) - одной из универсалий культуры повседневности в эпистолярии и прозе А.П. Чехова в хронологическом и поэтологическом аспектах. Автор прослеживает динамику функций костюма от ранней прозы к зрелой, выявляет механизмы формирования костюмных смыслов в чеховской прозе с учетом мифологического, жанрологического и нарратологического аспектов.

Структура монографии представлена в четырех взаимосвязанных главах.

Первая глава посвящена теоретико-методологическому аспекту изучения поэтики костюма. Обобщая подходы к изучению поэтики костюма, автор выявляет многообразие смыслов костюма и костюмных мотивов (архетипических, символических, интертекстуальных, биографических и т. д.) Поэтологический подход позволяет исследователю наиболее полно охватить совокупность смыслов костюмных мотивов, которые возникают на пересечении биографии и творчества не только в прозе, но и в эпистолярии А. П. Чехова. Учитывая содержание научной работы, методологический инструментарий позволяет произвести детальное изучение функций костюмной детали в историко-хронологическом аспекте творчества А. П. Чехова.

Автором монографии подробно исследован и проанализирован эпистолярий А. П. Чехова, который рассматривается как богатый источник костюмной информации. Обращается внимание на то, что костюм в письмах Чехова «особый способ проявления и построения себя». Костюм демонстрирует социальный статус, настроение, которое передается через вещь, создает «костюмные лейтмотивы». Так, чистота костюма, по мнению автора, приобретает у Чехова значение - «признак моральной благонадежности». В письмах, в частности в письмах к О. Л. Книппер-Чеховой, брату Александру, появляются игровые мотивы, которые в ранней прозе А.П. Чехова наделяют предмет скрытым игровым потенциалом. Именно в письмах, по мнению автора монографии, формируется чеховская игровая поэтика.

Вторая и третья главы показывают динамику функций костюма в творчестве А.П. Чехова в историко-хронологическом аспекте. В ранней прозе 
А. П. Чехова (1881-1887) Н. М. Абиева сводит функцию костюма (костюмной детали) к характерологии персонажа, при этом, на основе анализа рассказов «Сапоги», «Раз в год», «Месть», «Радость», Приданое», «На гвозде» и др. выявляет сюжетообразующую, символическую, психологическую функции костюмной детали, которая становится носителем подтекста (так, костюм может скрывать эмоции персонажа («Володя», 1887) или заслонять носителя костюма («Знакомый мужчина», 1886); в поздней прозе костюм будет связан с подтекстовым слоем («У знакомых, 1898-1903)).

Интересна мысль автора об особой роли костюмных зарисовок в ранних пародиях А. П. Чехова: «С одной стороны, именно костюм формирует пародийную ауру, с другой - открывает иной смысл, не дающий опрокинуть сюжет целиком в пародию. Многомерность текста, таким образом, создается неоднозначностью костюма».

При анализе поздней прозы А. П. Чехова («Рассказ неизвестного человека», «У знакомых», «Дом с мезонином», «В овраге») сделан вывод об усложнении костюмной детали, о появлении «многосмысленности костюма», которые возникают в результате пересечения историко-культурных смыслов. Таким образом, костюм становится звеном нарратива: «Костюмная деталь несет в себе, в свернутом виде, весь сюжет». Автор монографии наблюдает семантические сдвиги в поздней прозе А.П. Чехова: «визуальное» дополняется акустическими, ольфакторными, тактильными средствами и т. д. Костюм приобретает полифункциональность: несет метафизический смысл, выступает как интертекстуальная деталь, как костюм-лейтмотив и костюм-символ.

Весьма интересной представляется четвертая глава, в которой использование поэтологического подхода, рассматривающего костюм в аспекте метапоэтики, позволяет автору сделать вывод о межтекстовых связях костюмной детали в прозе А.П. Чехова. Благодаря сквозным образам (фуражка, шляпка, зонт, галстук, желтые башмачки, калоши, черное платье, бриллианты) в прозе А. П. Чехова создается эффект «мерцания» смысла: «Костюм в поздней прозе А. П. Чехова существует в межтекстовых связях: костюмная деталь, появившись в одном тексте, переходя в другой, сохраняя семантику, тянет за собой смыслы, закрепленные за ней, реализуя их в другом тексте: «перекликающиеся» детали задают лейтмотив, существующий в вариациях смыслов и неоднозначной семантике».

Заслуга Н.М. Абиевой в том, что впервые системно проанализирована костюмная поэтика в эпистолярии и прозе А. П. Чехова в хронологическом и поэтологическом аспектах. Автор монографии делает вывод о продуктивности семиотического подхода в изучении архетипического, фольклорно-мифологического, культурно-семантического смыслов костюма, а также 
выявляет наиболее органичный сюжетологический и нарратологический аспект в изучении чеховской поэтики костюма.

Монография Н. М. Абиевой - многоаспектное, комплексное исследование сюжетообразующей, нарративной, мифопоэтической, интертекстуальной и других функций костюма в поэтике А. П. Чехова. Автор показал, что костюм является полифункциональным явлением поэтики литературного текста.

Светлана Николаевна Черепанова

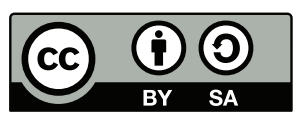

This work can be used in accordance with the Creative Commons BY-SA 4.0 International license terms and conditions (<https://creativecommons.org/licenses/by-sa/4.0/legalcode>). This does not apply to works or elements (such as images or photographs) that are used in the work under a contractual license or exception or limitation to relevant rights.

https://doi.org/10.5817/OS2021-1-12

\section{По ту сторону рационального}

Иррациональное в русской культуре. Сборник статей; сост., предисл. Ю. Маннхерц; пер. с англ. Н. Эдельмана. Москва: Новое литературное обозрение, 2020. 264 с. (Серия Studia Europaea). ISBN 978-5-4448-1201-3.

Современные реалии информационной среды вскрывают глубинные пласты иррационального в культуре. Научные открытия последних двух столетий, казалось, должны были укрепить позиции разума в качестве способа освоения действительности, но de facto мы видим, как во всех сферах человеческой деятельности возрастает интерес к «альтернативным формам сознания» [с. 11]. Поэтому сборник статей «Иррациональное в русской культуре», вышедший в 2020 году в издании «НЛО», кажется весьма актуальным. Он предлагает взглянуть на культуру России XIX-XXI веков через призму отношения к иррациональному.

Стереотипы рационального осмысления, сложившиеся в эпоху Просвещения, лишь прикрывали масштабы попыток сверх- или внерационального познания. Эти стереотипы отразились и в языке, закрепив в семантической структуре слов, описывающих иррациональный опыт, оценочные коннотации. В европейской культуре сформировалась бинарная оппозиция «рациональное мышление - аномальное состояние сознания» [с. 12]. По мнению Юлии Маннхерц, составителя сборника, все это во многом затрудняет «нейтральный разговор» [c. 10] об иррациональном. 